\title{
Coming Home: The Spiritual Journey of the Prodigal Son
}

\author{
Maria Leodevina C. Batugal
}

\section{ABSTRACT}

In this article, I reviewed the passage of the Prodigal Son in the context of the Lukan perspective and the reader then, is referred to Luke 15: 1131. This parable gives us an image of a loving and forgiving God whose mercy endures forever. This is the greatest love story which presents the depths of God's love. Several biblical scholars disclose that this parable guides us to new hope by allowing God to love, forgive us and accept his saving love.

Keywords: Conversion, God's grace, Luke 15:11-31, Prodigal Son.

\author{
Published Online: August 16, 2021 \\ ISSN: $2736-5514$ \\ DOI : $10.24018 /$ theology.2021.1.4.37 \\ Maria Leodevina C. Batugal* \\ St. Paul University Philippines, \\ Philippines. \\ (e-mail: lbatugal@ spup.edu.ph) \\ *Corresponding Author
}

\section{INTRODUCTION}

This is a review on the passage of the Parable of the Prodigal Son (for the complete parable, the reader is referred to the Lukan text [Luke 15:11-31]). The parable of the Prodigal Son is described as the greatest love story of mankind. It presents a God whose steadfast love is boundless and incredible who pursues each one of us persistently in a loving relationship by filling us up with his mercy, love, and compassion. His love and mercy endure forever. These features of God's mercy are revealed throughout the Old Testament scriptures. The English translations often mask the Hebrew terms affirming the depths of God's ever active and constant relationship with the community of Israel: chesed may express God's mercy, loving kindness, compassion, and steadfast love; derivatives of rechem which expresses divine 'womb love'; tsedaqah and emet suggest righteousness, divine loyalty, and faithfulness; mishpat indicates justice as explained by Washington [1].

Carter enlightens us that as anchored in the Old Testament revelations, Jesus brought out in a new perspective of God's unfailing love and mercy and to be a Christian in the Parable of the Prodigal Son [2]. Indeed, this parable is a story of a loving and a forgiving Father who himself is the main character of the said parable. He is a father who is rich in mercy and compassion for his children.

\section{THE COMING HOME OF A SON}

Delcorno explains that the Parable of the Prodigal Son is a narrative which became the ideal story to convey a discourse about $\sin$ and penance, grace, and salvation. It was established as the paradigmatic biography of any believer [3]. It is one of the best-known stories in the Bible which has captured the imagination of commentators, preachers and writers as Jack [4] puts it. The Lukan version shows a parable which is a moving story which Jesus has ever uttered. Not without reason this narrative is recorded as the greatest short story of mankind. It clarifies a situation in the Lukan communities which were struggling with the conversion of the lost and the wayward sinners. The story is indeed a revelation of a certain heartless callousness in the demand of the younger son when he said, "Father, give me the share of your estate that should come to me." The unquestioning and loving father who is the central figure in the parable never

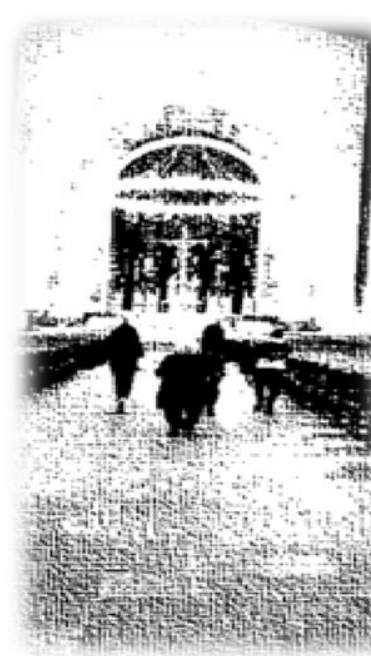
argued and with no malice, he lovingly granted his son's request. Without delay the younger son got his share and left home, went to a distant land and spent his wealth in loose and empty living. It was a moment of happiness and pleasure for him (Lk 15:13). Soon after he had spent almost everything, he experienced the dark days of exile; hunger plagued him, and even more, a lost dignity, shame, and humiliation, and plunged into a life of poverty and misery. In this critical, physical, psychological, and spiritual condition of starvation, the son "came to his senses." In his abject humiliation, he remembers and longs for the joys of his father's house. He returns repentant, planning to beg his father to take him in as a servant as explained by Veliyannoor [5]. He then, realized and said to himself, "I shall get up and go to my father and I shall say to him, 'Father, I have sinned against heaven and against you'," (Luke 15: 18). 
His return to the father is then recognized as a profound encounter of the younger son real "coming home," to his father which is an allusion to his spiritual conversion brought about by his starving condition of "death to a new life." It demonstrates his condition who have wandered away from life and must be brought back again by the pain and suffering he had encountered. He acknowledges his unworthiness before his father. However, his father images a loving God who fills the hungry with mercy and compassion. In the son's wandering, he was dead and lost; in his return, he is alive again and he is found."

Conversely, the reaction of the elder son in the parable is then told with equal understanding and sympathy. He had been faithful to the father but in so doing became selfrighteous, thinking that he "earned" his father's love and affection. Thus, he became resentful against his wayward brother being treated with tender loving affection. The banquet prepared for the brother's return to life illumines God's redemptive grace, mercy and love restoring the sinner to full life. This is the Christian meal which consequently an earthly reflection of the heavenly and angelic joy which accompanies the return of the repentant sinner.

In both ancient and modern standards, the exemplary father in the Parable of the Prodigal Son maybe is a foolish one, yet his foolish actions reveal an economy of grace that opens the door to repentance and reconciliation, by forgiving debts and exercising unaccountable generosity as elucidated by Eastman [6]. Certainly, the parable is an icon of spiritual conversion and the incredible loving mercy of God. The younger son as he "came to his senses" and coming home to his father symbolizes his true conversion (Luke 15:17) which is the recognition of one's sin; being truly sorry and repentant for one's sin; asking forgiveness for the sin; and showing purpose of amendment. This is the return from exile to our true home, as capture by the younger son in the parable.

Moreover, the parable offers us hope in God's loving forgiveness and His saving love. "The last act of Jesus on the cross is opening up his side (often understood by artists as referring to his heart), as it is pierced by a soldier (John 19:34), pouring forth the final ounce of blood and water, as a symbol of God's love, compassion, forgiveness, and redemptive celebration," writes Veliyannoor [5]. Thus, in this story, God is imaged by the father in the parable who patiently waited for the return of his son. He persistently inspires us through His grace to return to Him. He wants us to be reconciled to Him, to acknowledge before Him that we have sinned. The story as expressed in the work of Millet [7] is the tender revelation of the waiting father. His capacity to love without limits, to readily forgive, and to celebrate the return of a wandering son is as stunning as it is dramatically moving. It is, a glimpse into the soul of God, our Heavenly Father.

\section{The Parable of the Prodigal Son Leads Us to NEW HOPE}

The parable of the Prodigal Son is a parable for today. It offers hope for all who long for conversion. Reconciliation is an acknowledgment of our sins and a decision which leads to action, a decision to act upon it. "I shall get up and go to my father and I shall say to him, "Father, I have sinned against heaven and against you" (Luke 15: 18). Truly, sin is exile, enslavement to strangers and hunger as the younger son experienced in the parable. We realize that alienation from God can happen when sin controls our lives. Sin is losing the joy of communion with God; we defile and lose our spiritual life in God, and find ourselves away from our real home, our true self. It separates us from the love of God by rejecting God's gift of Himself to us which results in breaking our friendship and relationship with Him and others. Genuine repentance expresses a profound and a deep and intimate desire to come home, to pick up what we have lost and what we have

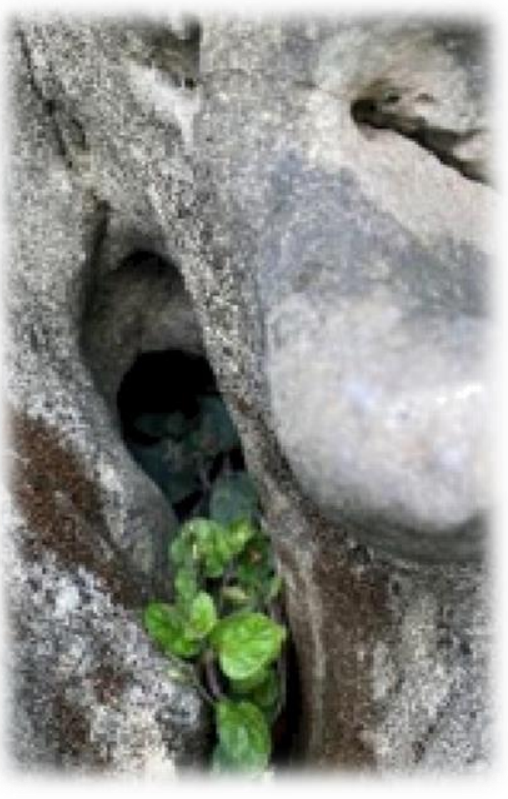
abandoned. The parable of the Prodigal Son moves us to discover the desire and power to return to our Heavenly Father. This is an edifying need to "come to our senses" and return to God in genuine and sincere repentance.

\section{CONCLUSION}

This parable leads a person to acknowledge God's grace. The grace of the Sacrament of Penance as we acknowledge our sinfulness and ask sincerely for Christ's pardon and mercy, God rejoices and accepts. The Parable of the Prodigal Son is a story which gives us the assurance of the unfathomable love and mercy of God amidst our weaknesses and frailties. He offers us the sacrament of Penance to give us the grace to renew our friendship with him and with others and brings us to a renewal of life, "metanoia," a change of heart, a profound change, a conversion to Christ with a solid decision pursuing the way to a good life which is the way of Christ. "Metanoia," calls for an enduring process of conversion that is inspired and empowered by the indwelling presence of the Holy Spirit which is supported and sustained by the other members of our Christian community. It is allowing God's grace to freely come into our lives and bring us back to our true and genuine self. This ongoing personal conversion calls us to continual conversion and renewal which is a constant turning away from sin and occasions of sin and renewing our spirit by acknowledging our sins, being truly sorry and firm in our purpose of amendment. Ongoing conversion urges us to acknowledge our sins with sincere repentance celebrated in the Sacrament of Penance, attend penitential celebrations and fervent celebrations of the Holy Eucharist which move us to prayer, almsgiving, fasting, and especially our daily acts of sacrifice, loving service, kindness, compassion, and forgiveness which is strongly captured in the CFC [8]. In this way, the sacrament acquires a more prominent role in the spiritual journey of every Christian and elicits significant implications for the life and mission of the 
church. Luke's presentation of God is a self-revelation, both his work and his person and shows that this Gospel presents God as the God of Israel who has accomplished the New Exodus through his divine Son by the Holy Spirit, resulting in salvation for all mankind as explained by Jackson [9].

\section{ACKNOWLEDGEMENT}

The author wishes to acknowledge St. Paul University Philippines for financing the publication of this article. Special thanks to the Director and staff of the Center for Publication and Research, Innovation and New Technologies (CPRINT) for the processing of this article and for its publication.

\section{REFERENCES}

[1] Washington HC., The Lord's mercy endures forever: Toward a postShoah reading of grace in the Hebrew Scriptures, Interpretation, 2000 Apr; 54(2):135-45.https://doi.org/10.1177/002096430005400203.

[2] Carter T., The forgiveness of sins, ISD LLC; 2016 Aug 25.

[3] Delcorno P., In the Mirror of the Prodigal Son: The Pastoral Uses of a Biblical Narrative (c. 1200-1550), Brill; 2017 Sep 25.

[4] Jack AM., The Prodigal Son in English and American Literature: Five Hundred Years of Literary Homecomings, Oxford University Press; 2018 Nov 30

[5] Veliyannoor PV., The Parable of a Father and Two Sons: Jungian Hermeneutics and Therapeutic Applications, Journal of Psychology \& Christianity, 2009 Dec 1; 28(4).

[6] Eastman S., The foolish father and the economics of grace, The Expository Times, 2006 Jul; 117(10): 402-5. https://doi.org/10.1177/0014524606067176.

[7] Millet RL., Lost and found: Pondering the parable of the Prodigal Son, Studies in the Bible and Antiquity, 2012;4(1):4.

[8] Commission on Catechesis and Catholic Education: Catechism for Filipino Catholics, Manila: Word and Life, 1997. url: https://epdf.tips/catechism-for-filipino-catholics-cfc.html.

[9] Jackson J., The God who acts: Luke's presentation of God, Journal of the Evangelical Theological Society, 2021 Mar 1;64(1):95-107.

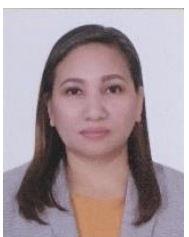

Maria Leodevina C. Batugal, $\mathrm{PhD}$ is a professor at $\mathrm{St}$ Paul University Philippines. She finished her Bachelor of Secondary Education (BSED) and Doctor of Philosophy in Education, major in Educational Management (PhDEM) in the same university where she is currently connected. She also graduated with the degree Master of Arts in Theological Studies at the Ateneo de Manila University, Quezon City, Philippines.

She is a professor both in the undergraduate level and graduate school and at the same time the university Quality Assurance Officer. She has written textbooks currently being used by the Junior High School in all Paulinian schools in the Philippines. She has published several researches and a reviewer in several journal publications. 